\title{
FAMOUS AMERICAN WAR SONGS
}

\section{By MaRshall BiDWell* .}

The history of a nation is written largely in its songs, which reflect, as nothing else does, the sentiment of the people in times of stress and great national crises. A knowledge of the origin of our familiar patriotic songs should give them a new and deeper interest and afford us a better understanding of the history of our Republic, and of the meaning of our hard-won liberty.

It may seem curious that so many of our earlier national anthems and war songs took their tunes from the English, as nearly all the Revolutionary songs are found to do. The popular tunes of that day, however, were mostly English and Irish, so it was only natural that the soldier songs, which are generally sung to old, well-known tunes or to popular tunes of the day, should be borrowed from them. This was especially true in the Continental Army, since there were no musical instruments with which to help spread and popularize new tunes. The British had a few horns, oboes, and flutes; the French had fairly good regimental bands; but the Continental troops had nothing but a few fifes and drums. And so we shall find that our national anthems, dating back to before the Revolution, were foreign tunes decked out with native words. In fact, it was not until many years after the Revolution that we had national music of our own.

As for the words of our American war songs, however, they date back to about a decade before the Battle of Bunker Hill, when the Colonists began writing ballads to express their dissatisfaction and their ideas about tea and taxation. The first of these patriotic songs to be published in America was "The Liberty Song," the words of which were written by John Dickinson, who was an ardent patriot, even though he had at first opposed the

*This article is condensed from one of the lectures of Dr. Bidwell, Organist and Director of Music, Carnegie Institute, delivered on the general subject of Our American Music, and reprinted from the Carnegie Magazine. 
Declaration of Independence because he felt that the colonies were not quite ready for it. Quaintly anticipating the later slogan, "Millions for defense, but not one cent for tribute," Dickinson's song begins:

In freedom we're born, and in freedom we'll live;

Our purses are ready; Steady, friends, steady;

Not as slaves but as freemen our money we'll give.

The Boston Tea Party inspired more songs, and when the Revolution actually broke out a really inspiring song was written-"Chester"- the "Over There" of the Revolution. Written by William Billings, sturdy Boston patriot and friend of Paul Revere, it shows its composer in deadly earnest. Despite the crudeness of the words and music, the sincerity of his utterance and perhaps the songs's very naivete endeared "Chester" to the troops. Originally composed as a church hymn, "Chester" was caught up by the Minute Men on the march and sung by thousands of foot-weary Continentals :

Let Tyrants shake their iron rod, And slav'ry clank her galling chains, We fear them not, we trust in God, New England's God forever reigns.

Evidently Billings thought God belonged to New England.

"Chester" was probably the most popular war song of the Revolution. Yet, today, it is mentioned only in histories, while "Yankee Doodle," its contemporary, lives on. That "Yankee Doodle" should ever have become a national song is a compliment to the American sense of humor.

During the French and Indian War, so the story goes, a certain Dr. Shuckburgh, who happened to be in Albany with the Brtiish redcoats when a contingent of raw Colonial reinforcements arrived in their ragged uniforms, stopped laughing at the sight of these recruits just long enough to write down some foolish verses to an old tune that had come over from England. There were so many different sets of words to this tune that now no one 
knows just which words Dr. Shuckburgh wrote. The verse that we know best today is:

\author{
Yankee Doodle came to town \\ Riding on a pony, \\ Stuck a feather in his cap, \\ And called it Macaroni.
}

A Macaroni in England was a fop or dandy, but just where the term, "Yankee," came from will always be a mystery, even though there are all sorts of theories. In any event, it was not considered a complimentary term when used by the British, and was indeed an insulting epithet when Captain Preston hurled it at a mob during the so-called Boston massacre. The word, "Doodle," comes from an English term meaning "Do-little" or "Silly," and the British taunted the Yankees with the song. One of the favorite pastimes of the British troops was to gather in front of the New England churches and sing "Yankee Doodle" as the congregation was singing psalms.

On that April night in 1775 when the British troops marched out of Boston toward Lexington to aid in the capture of John Hancock and Samuel Adams, they kept step to the strains of "Yankee Doodle," singing these words :

\author{
Yankee Doddle came to town \\ For to buy a firelock: \\ We will tar and feather him \\ And so we will John Hancock.
}

Ahead of them, though they did not know it, was a real Yankee-Paul Revere-and he was "riding on his pony." When the Colonials routed the British troops at Concord, affairs were in a complete turnabout, for the Yankees immediately appropriated the song as their own, and sang it back at the British as they fled. Since then it has been an American song, and when Cornwallis surrendered at Yorktown, the American band played it for that occasion.

It is not generally realized that the tunes for both 
"Hail, Columbia" and "The Star-Spangled Banner" were familiar in George Washington's time, even though they did not become national anthems until later. The tune of "Hail, Columbia" was just an instrumental band march, without words, written during Washington's administration by a German music teacher living in Philadelphia and known as "The President's March." The words written to fit this tune had their origin in the war we almost had with France in 1789. The two political parties, Federalists and Anti-Federalists, were hotly engaged in a dispute as to whether we should help England or France, and it was during this excitement that Joseph Hopkinson wrote the words of "Hail, Columbia" as a nonpartisan patriotic song that would be expressive of the American spirit. The words of the chorus,

$$
\begin{aligned}
& \text { Firm, united, let us be, } \\
& \text { Rall'ing round our liberty, } \\
& \text { As a band of brothers joined, } \\
& \text { Peace and safety we shall find. }
\end{aligned}
$$

were sung in a Philadelphia theater, and soon the whole city was singing them. Party lines were forgotten, for the time being anyway. "Hail Columbia" was born at a vital moment in our nation's history, and because it kindled and kept alive the American spirit by lifting it above strife and division of thought, it will always live in the hearts of the American people. We should remember this song for a very special reason: both words and music were products of Americans. In this respect it is said to be the first wholly American song.

Up to the time of the Spanish-American War "Hail, Columbia" shared honors with "The Star-Spangled Banner" as one of our national anthems, being played generally by European countries when paying homage to America, and also by the Navy bands when the flag was lowered at sunset. It was not until some time after 1898, when Admiral Dewey officially designated "The StarSpangled Banner" as our national anthem for the Navy, that "Hail, Columbia" lost its place. 
Most Americans who have struggled manfully to sing the tune of "The Star-Spangled Banner" would like to tar and feather its composer, so perhaps it is just as well that he is unknown. Its American use dates from 1793, when it became the official song of the several Anacreonic Societies in this country. This was some twenty years before the famous words were put to it. In 1798 it was known as "Adams and Liberty," and it is really bad luck that Francis Scott Key should have been so familiar with its unsingable tune, instead of one of the hundreds of other simple folk tunes that he could have used. For, as everyone knows, he wrote "The Star-Spangled Banner" under the stress of overpowering emotion, using the first melody that came to his mind. We can all imagine how we would have felt, watching the bombardment of Fort McHenry and then discovering that the old flag was still flying. No wonder he sang in his heart, "O long may it wave o'er the land of the free and the home of the brave." This was on the morning of September 13, 1814. The words were printed "To be sung to the tune, "Adams and Liberty" " and were first printed on a cheap handbill and later appeared in a Baltimore newspaper. Since then, its career has been history. "The Star-Spangled Banner" was by far the most significant heritage of the War of 1812.

Although the English tune, "God Save the King," was well known in the Colonies in different versions, the words of our national hymn, "America," belongs here chronologically. It appeared in 1831 , but it cannot be correctly classed as a war song. It is associated with no war, and voices no belligerent sentiments. In this regard it is unique among our early national airs; it is truly our national "hymn," and belongs in the same category as that other inspiring hymn, "America the Beautiful," which emphasizes the idea of brotherhood and the glory and dignity of the American spirit.

The next national song, in chronological order, "Columbia, the Gem of the Ocean," had its origin sometime between the War of 1812 and the Civil War. Although both 
verses and music were written by an actor and were plagiarized in London under the name "Britannia, the Gem of the Ocean," its history holds no romance. The rather shameful incident of the War with Mexico produced nothing very inspiring, either, so we can pass over this period without missing anything of importance.

No other war in our country's history produced as many songs as the Civil War. The struggle lasted so long, and the feeling on each side was so intense, that hundreds of songs of all degrees of merit appeared.

Strangely enough, the outstanding survivor of the songs of the Confederacy, "Dixie," was written by a Northerner, a blackface comedian from Ohio. He was a member of Dan Bryant's Minstrel Show, playing in New York in 1859. They needed a "walk-around" or "hurray" song, so Emmet sat down backstage and scribbled off this song and dance, which was a rollicking picture of the plantation with something of the dash and impertinence of "Yankee Doodle." It is about as typical an American folk song as may be found anywhere, with its reckless laughter and high, nervous mood. It made a sensation and soon all the minstrel troupes throughout the country were singing and dancing to it. When the war started Southern troops appropriated it-in spite of the North's attempts to recapture "Dixie" by writing new words-and it became the marching song of the Confederate Army. No one was more discouraged than the composer, a man of Union sympathies, when he became idealized by the South and denounced as a traitor by the North. Except for "Dixie," "The Bonnie Blue Flag" and "Maryland, My Maryland" were the most popular among Southern songs.

If the North gave to the South her chief song, "Dixie," the compliment was returned in the most important song of the Civil War, "Glory Hallelujah," or the "Battle Hymn of the Republic." This began down in Charleston as a Southern camp meeting Gospel hymn, "Say Brothers, will you meet us on Canaan's happy shore?" The writer was William Steffe, a popular composer of Sun- 
day-school music. From Charleston it traveled to Boston Harbor, and then to Washington, where Julia Ward Howe heard it sung-with different words-by soldiers riding into battle. She was transported by it and gladly consented to a suggestion of a friend that she write more fitting words than the soldiers had chosen for it. "Mine eyes have seen the glory of the Coming of the Lord," was the result. It was the poem of the hour, the Union armies taking it up as the great marching song of the North. It does not speak of boundary lines, however, and it has been sung ever since as a poem in which there is the spirit of all Americans everywhere.

A very different type of war song is "Tenting Tonight on the Old Camp Ground." The composer, Walter Kittredge, a ballad singer from New Hampshire, displays a typical New England business sense when he writes a song that would appeal to Blues and Grays alike. 'And yet, a careful reading of the words of this appealing song reveals the fact that it must have come from his heart.

One of the most popular sentimental ballads was "When Johnny Comes Marching Home," a hit by the famous band leader, Pat Gilmore, the man who preceded Sousa in his devotion to popular music of the better sort. Johnny has come marching gaily home from two wars since, to the tuneful, "Hurrah, Hurrah," of Gilmore's song.

The stirring "Battle Cry of Freedom" is of a very different type. As in the "Battle Hymn of the Republic," we find here the same crusading spirit with which the men of the North rallied to preserve the Union. When the President issued his second appeal for volunteers, the recruiting officers had some difficulty persuading men to enlist, so something had to be done. George Frederick Root, a Chicago music publisher and a well-known Gospel hymn composer wrote these words to meet the emergency:

We'll rally round the flag, boys,

Rally once again,

Shouting the battle-cry of freedom. 
Well, this song certainly had its effect. In both Chicago and New York excitement ran high and the "Rallying Song" proved to be a great force in swelling the ranks of the Union Army. Soldiers sang it as they marched, and from the year 1861 to the end of the war, this rousing song of patriotism was heard everywhere.

The story of Civil War songs would not be complete without mention of that intensely partisan song, "Marching Through Georgia." Celebrating an event which is intensely hateful to the South-Sherman's March from Atlanta to the Sea-it is one of the most characteristic songs of that War. The composer, Henry Clay Work, whose long beard reminds one of both the Smith brothers, was a writer of smash-hit tunes of the day. It is a pity that such a fine tune, with all the qualities of a national anthem, should have such a partisan inspiration.

When we think over the songs that have been written in recent years, we shall have to admit that nothing has been written to equal these Civil War songs. The feeling of sincerity is sadly lacking in the wars that followed, particularly during the Spanish-American War, from which only one song of consequence, "A Hot Time in the Old Town Tonight," came.

It is a mistake to assume that all war songs are patriotic. As a matter of fact, patriotic songs make up but a small fraction of wartime music. Their place is primarily behind the fighting lines, at patriotic meetings of civilians. Our soldiers take patriotism for granted and are not especially interested in singing about it. The experience of Army song leaders during the first World War was enlightening. Writers of heroic and patriotic songs were doomed to disappointment because the soldiers would have none of them. When men settle down to the serious business of fighting, marching, sleeping in the mud and the rain, their attention is more and more focused on the immediate details of their daily life. It is then that the true soldier songs are born, and naturally thoughts of home enter in.

To keep our troops cheerful was the sole purpose of 
our first World War songs, so, contrary to the serious crusading spirit of those of the Civil War, many of which survive today, the soldier songs of that period are almost always in a light, adventurous strain. "Hinky Dinky, Parley-Voo" and "Over There" are typical of these World War songs.

Of course, we must not overlook one thing: war songs are not written for posterity. If they have bolstered the troops' morale and kept their spirits high, they have served their purpose. But the later songs have lost character and the best of the Civil War songs, as well as many Foster favorites that have nothing to do with the war, are being sung today in the army.

of some fifteen favorites, the most rousing, and certainly the most popular, song of the World War, was "Over There," words and music by that grand old man of the stage, George M. Cohan. The French had their "Madelon," the English their "Tipperary," and the doughboys cheerfully joined them in singing these, but the darling of their hearts was "Over There." Its snappy march rhythm and the back-slapping vitality of its verse-beginning "Johnny get your gun, get your gun, get your gun"-acted as an immediate tonic when they were in danger of becoming downhearted. George $M$. Cohan put into this song his sense of the dramatic, and his sincere devotion to his country.

Of the songs of the present war, only time can tell which ones will stand the test-which ones will become really famous war songs. Someone has said, "Out of this war, with its far-flung lines stretching from Iceland to Australia, will come many a ballad as lusty as 'The Mademoiselle from Armentieres' or as stirring as 'The Caissons Go Rolling Along.' "

We all have begun to realize that we have serious trials ahead of us, perhaps unequalled in our history, and we need songs that will inspire us--not only songs that the army can use, but songs that will strengthen our spirits and keep our determination to win. The song writers of the past have set a stirring example for us to follow. 
We have reason to be proud of the great American songs of patriotism and freedom that have sung themselves into our hearts. The spirit of America is found in every line of these songs. Will another song as great as the "Battle Hymn of the Republic" come out of this war? Only time will tell.

\section{SONGS OF WORLD WAR II}

The spirit of patriotism is not lacking in America just now. The determination to conquer and control the bandits of Europe and the far Pacific, and restore freedom to enslaved peoples of the world stirs our people and gives our army and navy the urge to win.

But America did not enter World War II with any actual enthusiasm. No degree of eagerness or fervor marked our early course and there was no real relish for the duty at hand. The portent of pre-war developments was neither widely known or correctly understood. So, it was not strange that sentiment and ardor were lacking and only grim determination ruled after the first shock of the attack on Pearl Harbor.

Soon, however, the song writers and poets were busy penning lyrics and composing music to support morale and encourage the war spirit both on the home front and in the many battle areas where soldiers and sailors are carrying the flaming torch of freedom. Dr. Bidwell has not risked the naming of any of those which have caught the fancy of citizens or soldiery from the many airs which have been written and currently sung on the stage, reproduced on the sound track of the movies or over the radio. Eventually there may emerge a few that will express the spirited and patriotic emotions stirred in America and other countries where soldiers and sailors still sing and those at home give vent in melody to the desires of their hearts.

If rated according to their combined sales of sheet music and phonograph records the most popular war songs today would be "The White Cliffs of Dover," 
2,700,000 ; "Praise the Lord and Pass the Ammunition," 2,100,000; "There's a Star-Spangled Banner Waving Somewhere," 2,000,000 ; "When the Lights Go on Again," $1,800,000$; and "Army Air Corps," 1,400,000. In Britain they are singing "There'll Always Be An England" and "The White Ciffs of Dover," the latter really a pre-war song, as also was "God Bless America," the powerful popular hit here, but they must be classed as belonging to the present war. The latter is not just a hymn nor more prayerful than "Just Before the Battle, Mother" of Civil War memory.

Perhaps among those receiving the widest notoriety is "Praise the Lord and Pass the Ammunition," the sentiment based upon the heroic action of an unidentified chaplain in the Guadalcanal naval battle. Another attaining some degree of popularity, credited to an American soldier in Africa, is "Don't Sit Under the Apple Tree," evidently addressed to "the girl" back home. Such contributions as "We Did It Once, and Can Do It Again" and "Gertie From Bizerte," the latter also from the African war area, have been characterized as inferior to the tunes of World War I. Three of more lofty sentiment gaining some favor are "You're a Grand Old Flag," "Angel of Mercy" and the "March of the Women Marines."

There is some tendency to blame present restricted use of the productions of song writers on the part of their own controlling organization, but that is hotly denied by the leaders in the American Society of Composers, Authors and Publishers. After all, there is quite general recognition that the soldier of this war is a serious-minded individual and that the old-time hymns and other religious and strictly spiritual and inspirational songs and even anthems are being sung by the men over seas, as well as art and cultural subjects receiving more attention from those in the armed service of America than in previous wars. 
Copyright of Annals of Iowa is the property of State of Iowa, by \& through the State Historical Society of Iowa and its content may not be copied or emailed to multiple sites or posted to a listserv without the copyright holder's express written permission. However, users may print, download, or email articles for individual use. 